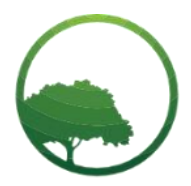

Research in Business \& Social Science

IJRBS VOL 11 NO 1 (2022) ISSN: 2147-4478

\title{
The prediction of financial distress probability in East Java province governments
}

\author{
(D) Rizky Aji Shiddiqy ${ }^{(a) *(1)}$ Nurkholis ${ }^{(b)}$ (D) Yeney Widya Prihatiningtias ${ }^{(c)}$ \\ (a) Accounting Department, Faculty of Economics and Business, University of Brawijaya, Malang, Indonesia \\ ${ }^{(b, c)}$ Faculty of Economics and Business, University of Brawijaya, Malang, Indonesia
}

\author{
A R T I C L E I N F O \\ Article history: \\ Received 16 December 2021 \\ Received in rev. form 01 Feb. 2022 \\ Accepted 06 February 2022 \\ Keywords: \\ Financial Distress Probability; East \\ Java; Province Governments; Local \\ Governments; Financial Indepence \\ JEL Classification: \\ I3
}

\begin{abstract}
A B S T R A C T
Beginning in the mid-1970s, financial distress in local governments became big news when New York City nearly collapsed due to the energy crisis and high inflation. When local governments experience financial distress, the responsibility to provide services to the community both now and in the future cannot be fulfilled. Local governments can only maintain services to the community if they are able to avoid financial distress. If the financial distress condition is maintained, there will be stagnation in the level of community welfare which will have an impact on regional economic growth because it is not supported by adequate public services. Some local governments like Pennsylvania, have implemented a measure to indicate financial distress as stipulated in the 1987 Financially Distressed City Act (UU 47). However, the local government in Indonesia does not yet have an absolute measure for this financial distress condition. For this reason, financial distress in this study will use a relative measure indicated by the probability value measured using a definition approach. The results of the study provide an overview of how the relevant values in local government financial statements are able to predict financial distress in local governments. The findings show that the variables intergovernmental revenue (IGR), financial independence (FIND), employee expenditure (EMPEX), capital expenditure (CAPEX), and operating position (OPPOS) have a significant effect and can be used as an alternative predictor of financial distress with a more comprehensive suitability with the financial characteristics of local government in East Java Province.
\end{abstract}

() 2022 by the authors. Licensee SSBFNET, Istanbul, Turkey. This article is an open access article distributed under the terms and conditions of the Creative Commons Attribution (CC BY) license (http://creativecommons.org/licenses/by/4.0/).

\section{Introduction}

Government through Presidential Regulation no. 02 of 2015 concerning the National Medium-Term Development Plan (RJPMN) 2015-2019 has set an average target of capital expenditure for local governments of $30 \%$ of total regional spending. However, in fact there are still many local governments that have realized capital expenditures below the ratio set in the RPJMN. This condition shows that the function of local government in providing public services to the community as confirmed by regional autonomy has not been fully achieved. Wasteful behavior that spends half of the budget only to finance employee expenses will bring local governments to the verge of bankruptcy or financial distress (Indriaty et al., 2019).

When local governments experience financial distress, the responsibility to provide services to the community both now and in the future cannot be fulfilled. Local governments can only maintain services to the community if they are able to avoid financial distress (Trussel, 2012; Ziolo, 2015). If the financial distress condition is maintained, there will be stagnation in the level of community welfare which will have an impact on regional economic growth because it is not supported by adequate public services (Sari \& Azra, 2019).

\footnotetext{
* Corresponding author. ORCID ID:

(C) 2022 by the authors. Hosting by SSBFNET. Peer review under responsibility of Center for Strategic Studies in Business and Finance.

https://doi.org/10.20525/ijrbs.v11i1.1561
} 
For the most part, the definition of financial distress describes what is experienced by the government as a result of the financial problems faced by the government (Trussel \& Patrick, 2009; Carmeli, 2008). The problem is then explained by Wang et al., (2007) and Arnett, (2011) as a condition where local governments are prone to having difficulty in funding their operations and experiencing increasing budget problems. In addition, Cohen et al., (2012) also explained that when local governments are too dependent on external funding sources, it can result in an increase in financial risk. This financial condition is then used as the basis for determining whether a local government has a high probability of experiencing financial distress.

Based on the results of previous studies, the authors are motivated to conduct research in order to predict the probability of financial distress, especially in local governments in East Java Province. The difference between this study and previous research is that it does not impose the use of variables related to financial distress in the business sector into the government sector. This study will provide alternative variables that will be categorized into categories of income, expenditure, operating position, and debt structure while still taking into account the applicable laws and regulations. In addition, this research will be conducted within a span of 7 years starting from 2013 to 2019 . Thus, the authors conducted a study with the title,

Based on the background that has been presented, the formulation of the problem in this study is: can financial ratios categorized based on income, expenditure, operating position, and debt structure be used to predict the probability of financial distress in local governments in East Java Province?

\section{Literature Review}

\section{Theoretical and Conceptual Background}

Agency theory was first put forward by Jensen \& Meckling (1976) which states that the agency relationship is a contract that occurs between two parties, namely the party who gives authority or power which is then referred to as the principal. The focus of agency theory is to determine the most efficient contract in managing the principal and agent relationship (Eisenhardt, 1989; Halim \& Abdullah, 2006). In relation to agency, the government must carry out what is in the interests of users of government financial information. If the agent cannot present information properly, this situation can lead to agency problems in the form of information asymmetry and conflicts of interest. (Faristina, 2011).

The signaling theory proposed by Spence (1973) discusses the form that signals of success or failure of management (agents) should be conveyed to owners (principals). Signal theory assumes that companies with superior performance (or good companies) use financial information to send signals to the market (Sumarlin, 2016). Signal theory is basically concerned with reducing information asymmetry.

Legitimacy theory assumes that entities do not have an inherent right to exist. This right is given to the entity by the community when the entity's operations are in accordance with the expectations of the surrounding community (Magness, 2006).

\section{Regional Autonomy \& Financial Management of Local Governments in Indonesia}

Indonesia is a unitary state in the form of a republic. Indonesia consists of 530 autonomous regional governments, 33 of which are provincial governments, 98 municipal governments and 399 district governments (Minister of Home Affairs Regulation No. 18/2013). Local government financial management is divided into three main parts, including budget preparation, budget execution, and accounting system. Local government budgets are the basis for local government financial management for one fiscal year.

\section{Local Government Financial Report}

In the Indonesian context, the reference for preparing financial statements for public sector organizations refers to the Government Accounting Standards (SAP) as outlined in PP no. 24 of 2005 which was later changed to PP No. 71 of 2010 after the change in the cash basis accounting method toward accrual to accrual basis. This standard then becomes a mandatory reference for all government organs both at the center and in the regions (Nordiawan, 2006: 135).

\section{Relevant Values as Qualitative Characteristics of Financial Statements}

Scott, (2003) explains that relevance is a qualitative characteristic of financial statements that is useful to assist users in predicting estimated future payments. Kieso and Weygandt (2005) also say that relevance can be related to the purpose of its use, namely for decision making. In relation to the objective of relevance, financial accounting measurement and reporting methods can be chosen so that they can help users of financial statements to make decisions that require accounting data.

\section{Financial distress in Local Government}

The concepts of bankruptcy and financial distress are very close and familiar to the business sector. However, in the government sector, many local governments in most countries cannot declare bankruptcy (Cohen et al., 2014). For this reason, the definition of financial distress appears as a term that can be interchanged with concepts such as fiscal distress, fiscal strain, fiscal crises, fiscal squeeze, poor fiscal health, poor financial condition or budget pressures. These terms are used to describe the difficulties the government faces in dealing with social, financial and economic difficulties. 


\section{Prediction of Financial Distress in Local Government}

According to Foster (1994) analysis of the company's financial statements can be used as a way to predict financial distress, there are several indicators or sources of information that can be used to predict financial distress conditions, which include the following.

i. Information from cash flow analysis.

ii. Information from the company's strategy analysis.

iii. Information from the analysis of financial statements that are compared with the financial statements of other entities.

iv. Information from the analysis of external factors, such as stock returns and bond ratings.

\section{Conceptual Framework and Hypothesis Development conceptual framework}

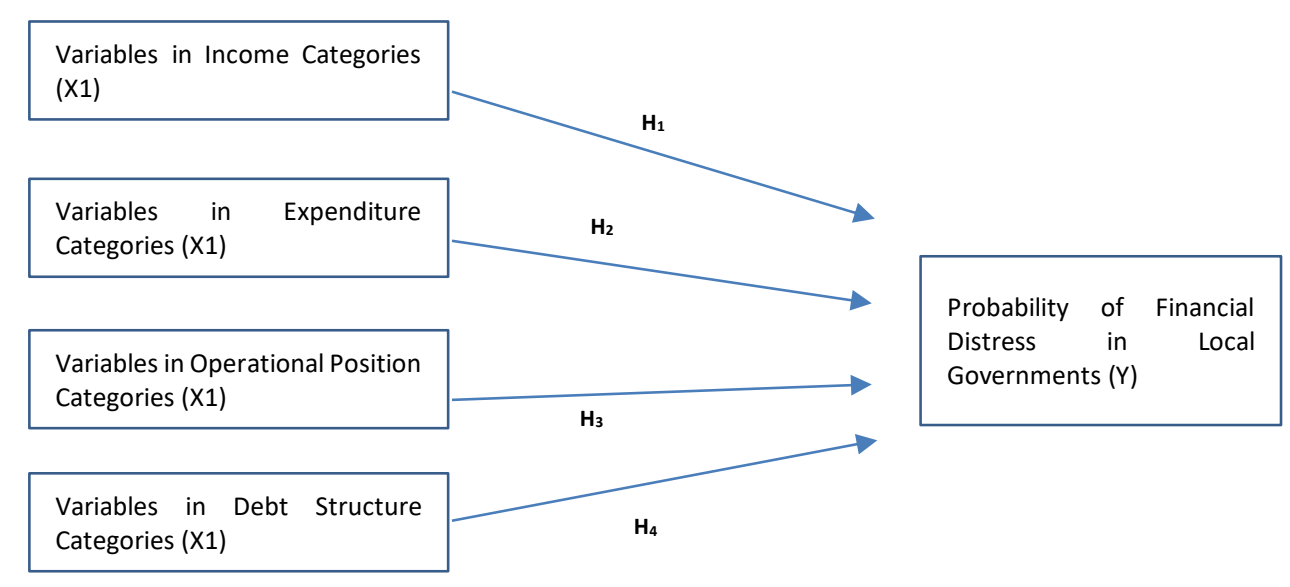

Figure 1: Conceptual Framework

\section{Research Hypothesis}

\section{Variables in Income Categories and Their Relationship in Predicting the Probability of Financial Distress in Local Governments}

\section{Intergovernmental Revenue}

In local governments in Indonesia, the source of local government funding which usually has the highest portion among other funding sources is the Balancing Fund. one of them is the General Allocation Fund (UU No. 33 of 2004). Based on the discussion above, local governments that have high sources of funding from other local governments are thought to have a tendency to experience financial distress. So the hypothesis of this research is as follows:

H1a: Intergovernmental Revenue (IGR) has a significant effect on the probability of local governments experiencing financial distress

\section{Financial Independence}

Own income to local governments in Indonesia, referred to as Regional Original Revenue (PAD) obtained from levies based on regional regulations in accordance with statutory regulations, (Law No. 33 of 2004). PAD is the right of local governments which is recognized as an addition to the value of the net worth obtained by the local government itself as long as the local government is able to maximize the potential of the area they have. Based on the discussion above, local governments are expected to be able to increase their own income and not be too dependent on other local governments, allegedly having a tendency to be able to avoid financial distress. Based on the discussion above, the hypotheses of this research are as follows:

H1b: Financial Independence (FIND) has a significant effect on the probability of local governments experiencing financial distress

\section{Revenue Execution Index}

Local government revenue budgets in Indonesia are regulated in PP 12 of 2019 although there is no specific regulation that requires that the revenue budget must be achieved, Gomez et al., (2009) find that the higher the value in this ratio indicates the better the local government in achieving the budget. previously set. With the achievement of a predetermined income, the local government can have a number of funds and regional expenditure activities can be realized. To support the variables related to the financial independence of local governments, the revenues execution index in this study will use the ratio of total local revenue compared to the total local revenue budget which is suspected to have an effect on financial distress in local governments, the hypothesis of this research is as follows:

H1c: Revenues Execution Index (REI) has a significant effect on the probability of local governments experiencing financial distress 


\section{Revenue Growth}

In this study, it is measured using the growth of total local government revenue for two years to be able to capture the value of the growth that occurs and is thought to have an effect on local government financial distress. So the research hypothesis is as follows:

H1d: Revenue Growth (RG) has a significant effect on the probability of local governments experiencing financial distress

A high value of per capita income indicates the higher the ability of local governments to generate more income for each individual resident and relative to changes in the population that occur. It is hoped that with the measurement of per capita income, local governments can have a reference at a certain population level, whether an area is able to produce an income level that is at least the same or even higher. Where the higher income is thought to reflect a lower tendency of financial distress. Based on the discussion above, the hypotheses of this research are as follows:

H1e: Revenue per Capita (REVCAP) has a significant effect on probability of local government experiencing financial distress

\section{Variables in the Expenditure Category and Its Relation in Predicting the Probability of Financial Distress in Local Governments}

\section{Operating Expenditure}

In Indonesia, regional expenditures are all regional government obligations that are recognized as a deduction from net worth in the period of the fiscal year. One of these expenditures is operating expenditure (PP 12 of 2019). Therefore, based on this explanation, the operating expenditure ratio calculated using the regional government's operating expenditure figures is thought to have an effect on financial distress in local governments. The research hypothesis is as follows:

H2a: Operating Expenditure (OPEX) has a significant effect on the probability of local governments experiencing financial distress

\section{Employee Expenditure}

Personnel expenditure is compensation in the form of money or goods given to civil servants in return for work that has been carried out in order to support the duties and functions of government organizational units (Minister of Finance Regulation Number 101/Pmk.02/2011). An increase in mandatory fees can make local governments less able to adjust to changes and will put pressure on local finances.Based on this explanation, the use of the ratio of personnel expenditure to total local government expenditure is thought to have an effect on financial distress in local governments, so the hypothesis of this study is as follows.

H2b: Employee Expenditure (EMPEX) has a significant effect on the probability of local governments experiencing financial distres

\section{Capital Expenditure}

Capital expenditure is believed to be a type of expenditure that is directly related to increasing community productivity, economic growth, and community welfare. Therefore, an analysis of capital expenditures can be carried out to determine its effectiveness and influence on financial distress. Based on this explanation, expenditures intended for the purpose of increasing capital are thought to have an effect on financial distress in local governments, the hypothesis of this research is as follows.

H2c: Capital Expenditure (CAPEX) has a significant effect on the probability of local governments experiencing financial distress

\section{Expenditures Execution Index}

Expenditures on public investment should receive greater attention than routine (administrative) expenditures, because investment/capital expenditures have long-term effects. Mistakes in making investment decisions will not only have an impact on the current year's budget, but will also burden the budget for the following years. Based on this explanation, the measurement of the regional capital expenditure ratio is thought to have an effect on financial distress in local governments, so the hypothesis of this study is as follows:

H2d: Expenditures Execution Index (EEI) has a significant effect on the probability of local governments experiencing financial distress

\section{Expenditure per Capita}

The size of per capita spending can be problematic if per capita income remains stable or if no new services are added by local governments (Trussel \& Patrick, 2018). Based on this explanation, the ratio of expenditure per capita is thought to have an effect on financial distress in local governments, so the hypothesis of this study is as follows:

H2e: Expenditure per Capita (Excap) has a significant effect on the probability of local governments experiencing financial distress 


\section{Variables in the Operational Position Category and Its Relation in Predicting the Probability of Financial Distress in Local Governments}

\section{Operating Position}

The operating position describes the local government's ability to balance revenues with expenditures. This ratio is used by the research of Groves, 1981 and Trussel \& Patrick, 2018. The higher the value shown in this ratio, the higher the income generated by the local government compared to its expenditure, on the contrary, the lower the value indicated, the lower the level of balance of availability. income for spending. Based on this explanation, the ratio of operating position is thought to have an effect on financial distress in local governments, so the hypothesis of this study is as follows:

H3a: Operating Position (OpPos) has a significant effect on the probability of local governments experiencing financial distress

\section{Deficit or Surplus}

In local governments in Indonesia, the difference between the regional revenue budget and the regional expenditure budget results in a surplus or deficit (PP 12 of 2019). Based on this explanation, the ratio of deficit or surplus is thought to have an effect on financial distress in local governments, so the hypothesis of this study is as follows:

H3b: Deficit or Surplus (DefSur) has a significant effect on the probability of local governments experiencing financial distress

\section{Operating Deficit or Surplus}

Local governments in Indonesia are required to compile an Operational Financial Report that presents an overview of economic resources that increase equity and their use which is managed by the central/regional government for government administration activities in one reporting period. (PP No. 71 2010). The fundamental difference in this report is the use of the accrual method. With this report, the operating surplus or deficit generated in the report will be different from the surplus or deficit conditions in the previous variable. Based on this explanation, the ratio of operating deficit or surplus is thought to have an effect on financial distress in local governments, so the hypothesis of this study is as follows:

H3c: Operating Deficit or Surplus (OpDefSur) has a significant effect on the probability of local governments experiencing financial distress

\section{Budget Balance Growth (SALG)}

In Indonesia this is known as the excess budget balance (SAL) which is a balance that comes from the accumulation, the remaining excess/less budget financing (SiLPA/SiKPA) in the previous and current budget years and other allowed adjustments (PP No. 71). 2010). Based on this explanation, the ratio of Budget Balance Growth (SALG) is thought to have an effect on financial distress in local governments, so the hypothesis of this study is as follows:

H3d: Budget Balance Growth (SALG) has a significant effect on the probability that local governments experience financial distress

\section{Consecutive Deficit (ConDef)}

This variable is used by Kloha et al., (2005) where the operating deficit for one year is considered a small sign of financial distress, but by measuring whether the government has an operating deficit for a year is considered as a small sign of financial distress. two years ago. operating deficit becomes a much more serious problem especially if it occurs sequentially. Based on this explanation, the ratio of consecutive deficits is thought to have an effect on financial distress in local governments, so the hypothesis of this study is as follows:

H3e: Consecutive Deficit (ConDef) has a significant effect on the probability of local governments experiencing financial distress

Variables in the Debt Structure Category and Its Relation in Predicting the Probability of Financial Distress in Local Governments

\section{Debt Structure}

Excessive and too burdensome debt levels can lead local governments to experience financial distress, especially if debt grows faster than the income base that supports the debt. Based on this explanation, the ratio of the debt structure is suspected to have an effect on financial distress in local governments, so the hypothesis of this study is as follows:

H4a: Debt Structure (DS) has a significant effect on the probability of local governments experiencing financial distress

\section{Short term solvency}

The higher shown in this ratio indicates the more current assets of the local government that can be used to cover current liabilities. and conversely, the lower the value shown in this ratio indicates the higher the obligations that must be borne by the current assets of the local government. Based on this explanation, the ratio of short term solvency is thought to have an effect on financial distress in local governments, so the hypothesis of this study is as follows: 
H4b: Short Term Solvency (STS) has a significant effect on the probability of local governments experiencing financial distress

\section{Cash Solvency}

The ratio of cash solvency is thought to have an effect on financial distress in local governments, so the hypothesis of this study is as follows:

H4c: Cash Solvency (CSolv) has a significant effect on the probability of local governments experiencing financial distress

\section{Debt to Revenue}

The ratio of debt to revenue is thought to have an effect on financial distress in local governments, so the hypothesis of this study is as follows:

H4d: Debt to Revenue (DebtRev) has a significant effect on the probability of local governments experiencing financial distress

\section{Debt per Capita}

The ratio of debt per capita is thought to have an effect on financial distress in local governments, so the hypothesis of this study is as follows:

H4e: Debt per Capita (DebtCap) has a significant effect on the probability of local governments experiencing financial distress.

\section{Research and Methodology}

This study is a quantitative study that attempts to examine the causal relationship between the independent variables (local government financial ratios) and the dependent variable (probability of financial distress in local governments). This research was conducted with a descriptive approach with an exploratory nature which aims to reveal broadly and deeply about the causes and things that affect the occurrence of something, especially the use of any financial ratios that can be used to predict the probability of financial distress in local governments.

\section{Research Samples and Observations}

Table 1: Research samples and observations

\begin{tabular}{|c|c|c|c|c|c|c|c|c|}
\hline Description & 2013 & 2014 & 2015 & 2016 & 2017 & 2018 & 2019 & Total \\
\hline Local Government Financial Report & 29 & 29 & 29 & 29 & 29 & 29 & 29 & 203 \\
\hline Municipal Financial Report & 9 & 9 & 9 & 9 & 9 & 9 & 9 & 63 \\
\hline Total & 38 & 38 & 38 & 38 & 38 & 38 & 38 & 266 \\
\hline
\end{tabular}

The population used in this study were all district and city governments in East Java Province. Based on the technique, in East Java Province, there are 38 local governments consisting of 29 district governments and 9 city governments that can be used as research samples.

The formula for calculating the operating expense ratio is as follows:

\section{Ratio of Operational Expenditure $=($ Operational Expenditure $) /($ Regional Original Income + Revenue Sharing Fund $)$}

Data analysis in this study uses logistic regression, this is because the dependent variable in this study is categorical data (high probability of financial distress and low probability of financial distress). Logistic regression is a special form of regression where the dependent variable is a non-metric / binary variable.

The binary logistic regression equation model in this study is as follows.

$$
\operatorname{Ln} \frac{P}{P-1}=\beta_{0}+\beta_{1} X_{1}+\beta_{2} X_{2}+\beta_{3} X_{3} \ldots \ldots+\beta_{n} X_{n}
$$

Where; $\quad \operatorname{Ln} \frac{P}{P-1}=$ probability of local government for financial distress and non-financial distress

$X_{1} \ldots \ldots \ldots X_{n}=$ financial ratios based on categories of income, expenditure, operating position, and debt structure.

$\beta_{1} \ldots \ldots \ldots \beta_{n}=$ regression coefficient. 


\section{Analysis and Findings}

In addition to these ratios, this study uses the probability variable for local governments to experience financial distress as the dependent variable which is determined based on the operating expenditure ratio and divides the results quartiles.

\section{Descriptive Statistics}

Table 2: Descriptive Statistics

\begin{tabular}{lllll}
\hline \hline \multirow{2}{*}{$\begin{array}{l}\text { Variable } \\
\text { Non-financial distress }\end{array}$} & & $\begin{array}{l}\text { Financial distress } \\
\text { N=67 }\end{array}$ & Mean & Std. Deviation \\
\cline { 2 - 4 } Mean & 0,7873 & Std. Deviation & 0,8682 & 0,03939 \\
\hline FIND & 0,1846 & 0,10125 & 0,0958 & 0,02075 \\
\hline REI & 1,0847 & 0,09964 & 1,0913 & 0,09912 \\
\hline REVGROW & 0,0839 & 0,10391 & 0,06457 \\
\hline REVCAP & 2709945,06 & 0,07688 & 530644,963 \\
\hline OPEX & 0,7887 & 1346937,370 & 1990879,60 & 0,06211 \\
\hline EMPEX & 0,4673 & 0,04807 & 0,07526 \\
\hline CAPEX & 0,2098 & 0,07184 & 0,7900 & 0,06259 \\
\hline EEI & 0,8051 & 0,04884 & 0,5424 & 0,07092 \\
\hline EXCAP & 2451582,94 & 0,12016 & 0,2094 & 471790,320 \\
\hline OPPOS & 1,1353 & 1384448,105 & 0,8634 & 0,05326 \\
\hline DEFSUR & 0,0234 & 0,12329 & 1858322,42 & 0,04041 \\
\hline OPDEFSUR & 0,2024 & 0,06051 & 1,0681 & 0,05063 \\
\hline SALG & $-4,7106$ & 0,10852 & 0,0106 & 0,47288 \\
\hline CONDEF & 0,1357 & 70,87791 & 0,2078 & 0,26477 \\
\hline DS & 0,0136 & 0,34331 & 0,1694 & 0,01327 \\
\hline STS & 52,1515 & 0,01421 & 0,0746 & 441,30443 \\
\hline CSOLV & 39,0147 & 204,90740 & 0,0090 & 360,94113 \\
\hline DEBTREV & 0,0138 & 151,94607 & 138,3306 & 24239,872 \\
\hline DEBTCAP & 40290,70 & 0,01416 & 111,2727 & 0,0101 \\
\hline SOurce: & 48092,163 & 17528,02 & \\
\hline
\end{tabular}

Source: results of data processing

Statistical descriptive test is used to provide a general description of the data used in the study. The description in question includes the average value and standard deviation. Based on 266 observations, there are 199 regions that are in a non-financial distress position, and as many as 67 local governments are in a financial distress position.

\section{Discussion of Research Results}

\section{Income Category}

The results of the analysis in the income category show that the variable with a p-value smaller than the alpha value $(\alpha=0.05)$ is shown in the Intergovernmental Revenue (IGR) and Financial Independence (FIND) variables. The p-value on the IGR variable shows a value of 0.002 , or less than the value of $=0.05(0.002<0.050)$. In addition, the p-value of the FIND variable shows a value of 0.000 , or less than the value of $=0.05(0.000<0.050)$. This shows that there is a significant influence on the independent variables FIND and IGR on the dependent variable the probability of local governments experiencing financial distress, so it can be concluded that H1a \& H1b are acceptable. While the variables in other income categories such as Revenues Execution Index (REI), Revenue Growth (RG), and Revenue per Capita (REVCAP) shows that there is no significant effect on the dependent variable of the probability that local governments experience financial distress. This is indicated by the p-value on the REI variable showing a value of 0.267 , greater than value of $=0.05(0.267>0.050)$. The RG variable shows a value of 0.686 , greater than the value of $=0.05(0.686>$ 0.050). And the REVCAP variable shows a value of 0.597 , greater than the value of $=0.05(0.597>0.050)$ so it can be concluded that H1c, H1d, and H1e are rejected.

\section{Expenditure Category}

The results of the analysis in the expenditure category showed that the variable with a p-value smaller than the alpha value $(\alpha=0.05)$ was shown in the Employee Expenditure (EMPEX) and Capital Expenditure (CAPEX) variables. The p-value of the EMPEX variable shows a value of 0.001 or less than the value of $=0.05(0.001<0.050)$. In addition, the $p$-value of the CAPEX variable shows a value of 0.004 , or smaller than the value of $=0.05(0.004<0.050)$. This shows that there is a significant effect on the independent variables 
EMPEX and CAPEX on the dependent variable on the probability of local governments experiencing financial distress, so it can be concluded that $\mathrm{H} 2 \mathrm{~b} \& \mathrm{H} 2 \mathrm{c}$ are acceptable. While the variables in other spending categories such as Operational Expenditure (OPEX), Expenditures Execution Index (EEI), Expenditure per Capita (ExCap) shows that there is no significant effect on the dependent variable of the probability that local governments experience financial distress. This is indicated by the p-value on the OPEX variable showing a value of 0.435 , greater than the value of $=0.05(0.435>0.050)$. The EEI variable shows a value of 0.612 , which is greater than the value of $=0.05(0.612>0.050)$. And the EXCAP variable shows a value of 0.692 , greater than the value of $=0.05(0.692>$ 0.050 ) so it can be concluded that $\mathrm{H} 2 \mathrm{a}, \mathrm{H} 2 \mathrm{~d}$, and $\mathrm{H} 2 \mathrm{e}$ are rejected.

\section{Operation Position Category}

The results of the analysis in the operating position category show that the variable with a p-value smaller than the alpha value $(\alpha=$ 0.05 ) is shown in the Operating Position (OPPOS) variable. The p-value of the OPPOS variable shows a value of 0.000 , smaller than the value of $=0.05(0.000<0.050)$. This shows that there is a significant effect on the independent variable OPPOS on the dependent variable of the probability of local governments experiencing financial distress, so it can be concluded that H3a is acceptable. While the variables in other operating position categories such as Deficit or Surplus (DEFSUR), Operating Deficit or Surplus (OPDEFSUR), Budget Balance More Growth (SALG), Consecutive Deficit (CONDEF) shows that there is no significant effect on the dependent variable of the probability that local governments experience financial distress. This is indicated by the p-value of the DEFSUR variable showing a value of 0.691 , which is greater than the value of $=0.05(0.691>0.050)$. The OPDEFSUR variable shows a value of 0.983 , which is greater than the value of $=0.05(0.983>0.050)$. The SALG variable shows a value of 0.824 , which is greater than the value of $=0.05(0.824>0.050)$. The CONDEF variable shows a value of 0.817 , greater than the value of $=0.05(0.817>0.050)$ so it can be concluded that $\mathrm{H} 3 \mathrm{~b}, \mathrm{H} 3 \mathrm{c}, \mathrm{H} 3 \mathrm{~d}$, and $\mathrm{H} 3 \mathrm{e}$ are rejected. 983 , greater than the value of $=0.05(0.983>0.050)$. The SALG variable shows a value of 0.824 , which is greater than the value of $=0.05(0.824>0.050)$. The CONDEF variable shows a value of 0.817 , greater than the value of $=0.05(0.817>0.050)$ so it can be concluded that $\mathrm{H} 3 \mathrm{~b}, \mathrm{H} 3 \mathrm{c}, \mathrm{H} 3 \mathrm{~d}$, and $\mathrm{H} 3 \mathrm{e}$ are rejected. 983 , greater than the value of $=0.05(0.983>0.050)$. The SALG variable shows a value of 0.824 , which is greater than the value of $=0.05(0.824$ $>0.050)$. The CONDEF variable shows a value of 0.817 , greater than the value of $=0.05(0.817>0.050)$ so it can be concluded that $\mathrm{H} 3 \mathrm{~b}, \mathrm{H} 3 \mathrm{c}, \mathrm{H} 3 \mathrm{~d}$, and $\mathrm{H} 3 \mathrm{e}$ are rejected.

\section{Debt Structure Category}

The results of the analysis on the debt structure category for all variables including Debt Structure (DS), Short Term Solvency (STS), Cash Solvency (CSOLV), Debt to Revenue (DEBTREV), and Debt per Capita (DEBTCAP) do not show any variables with a p value -value is smaller than the alpha value $(\alpha=0.05)$. The $\mathrm{p}$-value on the DS variable shows a value of 0.514 , which is greater than the value of $=0.05(0.514>0.050)$. The $\mathrm{p}$-value on the $\mathrm{STS}$ variable shows a value of 0.701 , which is greater than the value of $=0.05$ $(0.701>0.050)$. The $\mathrm{p}$-value of the CSOLV variable shows a value of 0.654 , which is greater than the value of $=0.05(0.654>$ 0.050). The p-value of the DEBTREV variable shows a value of 0.599, which is greater than the value of $=0.05(0.599>0.050)$. The $\mathrm{p}$-value of the DEBTCAP variable shows a value of 0.954 , which is greater than the value of $=0.05(0.954>0.050)$.

\section{Conclusion}

This study aims to obtain empirical evidence that financial ratios categorized based on income, expenditure, operating position, and debt structure have an influence and can be used in predicting the probability of financial distress in local governments in East Java Province. The results of model testing using binary logistic regression show that financial ratios in the income category are the intergovernmental revenue (IGR) variable which explains the level of intergovernmental income and financial independence (FIND) which explains the level of local government income from their own sources. In the expenditure category, the variable employee expenditure (EMPEX) which explains related to local government capital expenditure and capital expenditure (CAPEX) which explains related to local government employee expenditures. In the category of operating position, namely operating position (OPPOS), which explains the amount of revenue that can be generated by the regional government for the portion of its expenditure. has a significant influence on the probability of financial distress in the local government of East Java Province. Meanwhile, for variables in the debt structure category, none of the variables that have an influence were found. Structurally, the local government, especially in East Java Province, is not too dependent on debt funding from external parties. In the category of operating position, namely operating position (OPPOS), which explains the amount of revenue that can be generated by the regional government for the portion of its expenditure. has a significant influence on the probability of financial distress in the regional government of East Java Province. Meanwhile, for variables in the debt structure category, none of the variables that have an influence were found. Structurally, the local government, especially in East Java Province, is not too dependent on debt funding from external parties. In the category of operating position, namely operating position (OPPOS), which explains the amount of revenue that can be generated by the regional government for the portion of its expenditure. has a significant influence on the probability of financial distress in the regional government of East Java Province. Meanwhile, for variables in the debt structure category, none of the variables that have an influence were found. Structurally, the local government, especially in East Java Province, is not too dependent on debt funding from external parties. Meanwhile, for variables in the debt structure category, none of the variables that have an influence were found. Structurally, the local government, especially in East Java Province, is not too dependent on debt funding from external parties. Meanwhile, for variables in the debt structure category, none of the variables that have an influence were found. Structurally, the local government, especially in East Java Province, is not too dependent on debt funding from external parties. 
This study also succeeded in proving that the prediction model developed based on financial ratios had a significant effect and a suitability for use and fairly strong predictive success with a percentage correct value of $93.6 \%$. Thus, users of local government financial statements can use the information in local government financial statements in making economic decisions, especially early detection information related to the probability of financial distress in local governments. The results of this study support the empirical evidence of previous studies that information on financial statements categorized into income, expenditure, operating position has an influence and can be used to predict the probability of local government financial distress as done by Groves, 1981; New York State Comptroller's Office, 2006; Brown, 1980; Kloha et al., 2005; Wang et al., 2007; Trussel and Patrick, 2018.

Author Contributions: Conceptualization, R.A.S., N., Y.W.P.; Methodology, R.A.S., N., Y.W.P.; Data Collection, R.A.S., N., Y.W.P.; Formal Analysis, R.A.S., N., Y.W.P.; Writing—Original Draft Preparation, R.A.S., N., Y.W.P.; Writing—Review And Editing, R.A.S., N., Y.W.P.; All authors have read and agreed to the published the final version of the manuscript.

Institutional Review Board Statement: Ethical review and approval were waived for this study, due to that the research does not deal with vulnerable groups or sensitive issues.

Data Availability Statement: The data presented in this study are available on request from the corresponding author. The data are not publicly available due to privacy.

Conflicts of Interest: The authors declare no conflict of interest.

\section{References}

Brown, KW (1993). The 10-point test of financial condition: Toward an easy-to-use assessment tool for smaller cities. Government Finance Review, 9, 21-21.https://doi.org/10.1016/0929-1199(94)90004-3

Carmeli, A. (2008). The fiscal distress of local governments in Israel: Sources and coping strategies. Administration and Society, 39(8), 984-1007.https://doi.org/10.1177/0095399707309358

Cohen, S., Costanzo, A., \& Manes-Rossi, F. (2017). Auditors and early signals of financial distress in local governments. Managerial Auditing Journal, 32(3), 234-250.https://doi.org/10.1108/MAJ-05-2016-1371

Indriaty, N., Setiawan, D., \& Pravasanti, YA (2019). the Effects of Financial Ratio, Local Size and Local Status on Financial Distress. International Journal of Economics, Business and Accounting Research (IJEBAR), 3(01), 38. https://doi.org/10.29040/ijebar.v3i01.381

Kloha, P., Weissert, CS, \& Kleine, R. (2005a). Developing and testing a composite model to predict local fiscal distress. Public Administration Review, 65(3), 313-323. https://doi.org/10.1111/j.1540-6210.2005.00456.x

Kloha, P., Weissert, CS, \& Kleine, R. (2005b). Someone to watch over me: State monitoring of local fiscal conditions. American Review of Public Administration, 35(3), 236-255.https://doi.org/10.1177/0275074005277435

Sari, M., \& Arza, FI (2019). The Influence of Regional Government Characteristics on Financial Distress Conditions for Regency and City Governments in Indonesia for the 2015-2017 Period. Forum for Accounting Research, 7(1), 1425.https://doi.org/10.24036/wra.v7i1.104566

Trussel, J. M., \& Patrick, P. A. (2009). A predictive model of fiscal distress in local governments. Journal of Public Budgeting, Accounting \& Financial Management, 21(4), 578-616. https://doi.org/10.1108/jpbafm-21-04-2009-b004

Trussel, J. M., \& Patrick, P. A. (2012). A Survival Analysis of U.S. Municipalities in Fiscal Distress. International Journal of Public Administration, 35(9), 620-633. https://doi.org/10.1080/01900692.2012.661189

Trussel, JM, \& Patrick, PA (2018). Assessing and ranking the financial risk of municipal governments: The case of Pennsylvania. Journal of Applied Accounting Research, 19(1), 81-101.https://doi.org/10.1108/JAAR-05-2016-0051

Wang, X., Dennis, L., \& Tu, Y. Sen Jeff. (2007). Measuring financial condition: A Study of US States. Public Budgeting and Finance, 27(2), 1-21.https://doi.org/10.1111/j.1540-5850.2007.00872.x

Zafra-Gómez, JL, López-Hernández, AM, \& Hernández-Bastida, A. (2009a). Developing a model to measure financial condition in local government: Evaluating service quality and minimizing the effects of the socioeconomic environment: An application to Spanish municipalities. American Review of Public Administration, 39(4), 425449.https://doi.org/10.1177/0275074008320710.

Publisher's Note: SSBFNET stays neutral with regard to jurisdictional claims in published maps and institutional affiliations.

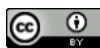

(C) 2022 by the authors. Licensee SSBFNET, Istanbul, Turkey. This article is an open access article distributed under the terms and conditions of the Creative Commons Attribution (CC BY) license (http://creativecommons.org/licenses/by/4.0/).

International Journal of Research in Business and Social Science (2147-4478) by SSBFNET is licensed under a Creative Commons Attribution 4.0 International License. 